\title{
ANNOTATION
}

\section{Blindness in India}

An interesting survey of Blindness in India by Sukumar Bagghi is contributed to the December, 1934, number of the Calcutta Medical Journal. His figures are taken from the 1931 census report. The population of India in that year was computed at $352,837,778$, of whom 601,370 were blind. The definition of blindness on which these figures are based was "inability to count fingers of a hand held up at a distance of one yard." Only those blind of both eyes were included in these statistics.

The author's first table gives the proportion of blind to the entire population and literacy; the blind being taken as per 100,000 of population and the literates as per 1,000 . In this table, Burma, with the largest number of literates (sic) (368 per mille) has 2.5 times more blind than Bengal, where the number of literates is a third that of Burma. Travancore, with a high proportion of literates, has a low proportion of blindness $(63$ per 100,000$)$. The author is of opinion "that illiteracy has contributed handsomely to this large quota of blindness."

The second table gives the relation of sex and age to blindness. Up to the age of 35 years the number of blind females is slightly lower than that of blind males; but, after the age of 35 years, the number of female blind is higher than the males. The author says: "Up to the age of 35 years both males and females suffer equally from eye diseases and have an almost equal chance of blindness, but the male has to do more arduous work and has the greater chance of blindness from injury. After 35 years the susceptibility to eye disease is equal in both sexes, but whereas the males have recourse to treatment by going to hospitals or doctors, the females spend most of their time in the smoky atmosphere of their houses, because of their innate shyness and ignorance; do not seek medical aid, and thereby run an increasing risk of blindness.

The exact climatic conditions conducing to the causation of blindness are as yet undetermined, but it is found that the figures of blindness on the whole are heavier in the drier, dustier and more sandy parts of India.

The second part of the author's paper deals with statistics he took in the year 1932 while working at the Eye Infirmary Medical College, Calcutta. He collected 3,330 cases, of which 2,203 were males and 1,12i females. Of these, blindness was of both eyes in 1,034 cases and of one eye in 2,206 cases. 
The Calcutta Blind School at Behala during the same year yielded 52 blind males and 22 females in the total of 74 inmates.

An elaborate table gives the causes of blindness in India. These are contrasted with similar tables prepared by Trousseau, in 1892, and by Magnus in 1870 .

In the author's series senile cataract stands far and away supreme as the cause of blindness in India; next come injury, trachoma, corneal leucomata, keratomalacia, glaucoma, cyclitis and iritis, anterior staphyloma, corneal ụlcer, optic atrophy, congenital cataract and small pox, in that order.

The European authorities, of many years ago, gave optic atrophy and purulent ophthalmia as the principal causes of blindness. Bagghi does not wish to compare his series with those of European authors too seriously as preventive medicine has made such great strides in the past half century. His figures show that purulent ophthalmia in India accounts for only 1.26 per cent. of blindness as against $\mathbf{1 6 . 1 6}$ per cent. (Trousseau), and 11.78 per cent. (Magnus.)

One of his cases was a pterygium in a Hindu woman, aged 39 years, who preferred blindness to simple operative interference.

\section{ABSTRACTS}

\section{MISCELLANEOUS}

(1) Schieck, F. (Würzburg).-Autogenous blood injection into the anterior chamber in cases of tuberculosis of the anterior segment of the eye. (Die Ergebnisse der Eigenblutinjektion in die vordere Kammer der Tuberkulose des vordern Bulbusabschnittes). Klin. Monatsbl. f. Augenheilk., Vol. XC, p. 1, 1933.

(1) Schieck reports on 19 cases of anterior segment tuberculosis treated by replacement of the aqueous by autoserum. No deleterious effects were noted even when the reaction was severe. In one case and also in two cases of sympathetic ophthalmitis no good was achieved; in all the others there was rapid and surprising improvement after one or more injections. Increase of tension was not noted in any case even when the blood was long in being absorbed. In injecting blood from the patient's arm into the emptied anterior chamber, a quantity enough to cover the iris and pupil 